\title{
Effects of feeding systems and breed group on carcass characteristics and meat quality of feedlot goat kids
}

\section{Efeito do sistema de alimentação e grupo racial nas características de carcaça e qualidade de carne de caprinos confinados}

\author{
Pedro Paulo Sobolow de Souza ${ }^{1}$; Helen Fernanda Barros Gomes ${ }^{2 *}$; Heraldo Cesar \\ Gonçalves $^{3}$; Paulo Roberto Lima Meirelles 3 ; Raquel Ornelas Marques ${ }^{4}$; Evelyn \\ Prestes Brito ${ }^{4}$; Giuliana Micai de Oliveira ${ }^{4}$; Hugo Lennon Corrêa ${ }^{4}$
}

\begin{abstract}
The goal was to evaluate if feeding systems with or without milk or breed groups can improve carcass characteristics, the proportion of tissues and meat tenderness of feedlot goat kids. Were used 56 animals from five different breed groups fed by experimental diet and milk according to the treatment., without milk or with $1,5 \mathrm{~L}$ milk/animal/day. The kid goats were slaughtered at $30 \mathrm{~kg}$ of live weight, and the carcass conformation and amount of fat were determined subjectively by visual assessment. Morphometric measurements and carcass and cut yields were performed. The Longissimus lumborum muscle was separated to determinate the area and subsequently it was used to evaluate the tenderness of the meat. The feeding system changes goat carcass characteristics, and goat kids fed milk until slaughter have better carcass yield and meat quality, as it anticipates the deposition of total fat, which can benefit carcass quality, given the scarcity of fat in the carcass of goats. The breed group also influences carcass characteristics. It is recommended the use of the Boer breed up to $3 / 4$, since more than that it reduces leg yield and does not improve the compactness index and carcass conformation.
\end{abstract}

Key words: Body weight gain. Goats. Milk. Nutrition.

\section{Resumo}

O experimento foi realizado com o objetivo de avaliar os efeitos do sistema de alimentação e grupo racial nas características de carcaça, no rendimento dos tecidos do lombo e maciez da carne de caprinos confinados. Foram utilizados cinco grupos raciais, sendo: Alpino, Anglo-Nubiano, 1/2 Boer x 1/2 Alpino, 3/4 Boer x Alpino e 7/8 Boer x Alpino), e os sistemas de alimentação foram: dieta experimental sem leite e dieta experimental mais $1,5 \mathrm{~L}$ de leite/animal/dia. Os animais foram abatidos após atingirem $30 \mathrm{~kg}$ de peso vivo, e foram avaliadas medidas morfométricas, rendimento comercial da carcaça, índices de compacidade da carcaça e da perna, rendimento de cortes comerciais. Sendo o corte Lombo separado para dissecção e determinação das proporções de músculo, osso, gordura e outros componentes. O músculo Longissimus lumborum foi também separado para avaliação da maciez. O sistema de alimentação alterou as características da carcaça de caprinos, e os animais alimentados com leite até

1 Prof. Dr., Universidade de Rio Verde, UniRV, Rio Verde, GO, Brasil. E-mail: sobolow@unirv.edu.br

2 Prof $^{\mathrm{a}} \mathrm{Dr}^{\mathrm{a}}$, Universidade Federal de Mato Grosso, UFMT, Campus de Rondonópolis, MT, Brasil. E-mail: gomeshfb@gmail.com

3 Profs. Drs., Universidade Estadual Paulista "Julio de Mesquita Filho", UNESP, Campus de Botucatu, Botucatu, SP, Brasil. E-mail: heraldo@fmvz.unesp.br; paulom@fmvz.br

4 Discentes, Curso Zootecnia, Programa de Pós-Graduação, UNESP, Campus de Botucatu, Botucatu, SP, Brasil. E-mail: ra_ ornelas@yahoo.com.br; evelynprestes@hotmail.com; hlcorrea.zoo@gmail.com; giuliana.micai@gmail.com

* Author for correspondence 
o abate apresentaram melhor rendimento de carcaça e melhor qualidade da carne. O cruzamento do grupo racial Boer com o Alpino aumentou a proporção de tecido muscular depositado, caracterizando dessa forma uma carcaça de melhor qualidade, mas a maciez da carne não foi influenciada pelo grupo racial e sistema de alimentação. O grupo racial também influenciou nas características de carcaça, sendo recomendada a participação da raça Boer até $3 / 4$, já que acima disso, além de não melhorar o índice de compacidade e a conformação da carcaça, reduz o rendimento da perna. O sistema de alimentação com leite antecipa a deposição de gordura total, que pode beneficiar a qualidade da carcaça, tendo em vista a escassez de gordura na carcaça de caprinos.

Palavras-chave: Ganho peso. Cabra. Leite. Nutrição.

\section{Introduction}

Although in Brazil there is still no standard for the marketing of goat carcasses, assessments of the influence of breed groups and management practices should be available to guide farmers and technicians in the pursuit of excellence.

Quality carcasses must have a high proportion of muscle and small of bones and proper intramuscular fat content, to ensure juiciness and flavor of the meat, besides a minimum of fat cover (RODRIGUES, 2009). Goat carcasses in general are poor in fat cover, which is beneficial from a nutritional point of view, but it difficults the process of cold storage (DELFA et al., 1992), which is a problem for the meatpacking industry.

The breed group and feeding system direct influence on animal carcass characteristics. The Boer breed, for example, has been widely used to improve growth and carcass traits of local breeds through breeding (GOMES et al., 2011). Nonetheless, feeding those animals may be expensive to the production system, but there are regions where the excess milk from the farms during the period from September to December (milk harvest) can be used for feeding meat goat kids. Therefore, it is necessary to evaluate the influence of the milk on performance and carcass characteristics of animals fed with it.

In this regard, monitoring animal performance and some biometric measurements become important for evaluating carcass development (MANFREDINI et al., 1988). Some measurements can be used to characterize the product, and the proportion of cuts in the carcass allows a qualitative assessment since a good carcass must present the best possible proportion of cuts with higher content of edible tissues, especially muscle (YÁÑEZ, 2002), allowing better use for cooking and making commercialization easier (RODRIGUES, 2009).

For that reason, feeding systems or breed groups that provide increases in carcass yield and tenderness of the meat may represent an interesting alternative to the farmer in the improvement of the products, and with it, the possibility of increasing income.

Given the foregoing, the goal of this paper was to evaluate the effects of feeding system and breed group on carcass characteristics, the proportion of loin tissues and meat tenderness of feedlot goat kids.

\section{Material and Methods}

Were used 56 animals from five different breed groups: six Alpine males and four females, eight Anglo Nubian males and eight females, four $1 / 2$ Boer $x$ Alpine males and six females, four $3 / 4$ Boer $\mathrm{x}$ Alpine males and five females and five $7 / 8$ Boer $\mathrm{x}$ Alpine males and six females.

After birth, the kid goats were separated from the does and received the same treatment regarding the umbilical cord, identification and feeding up to 60 days old. At this point, milk was no longer provided for half of the kids from each breeding group; these animals formed the group that was fed without milk. The animals in the other half of each group continued to receive $1.5 \mathrm{~L}$ milk/day at a single morning feeding until they were slaughtered; 
these animals constitute the group that was fed with milk. From the second week after birth, the animals had access to ground concentrate ad libitum in both treatments.

All males were surgically castrated at 30 days old. Subsequently, they were housed in 10 collective pens according to the feed system and breed group until they reached $30 \mathrm{~kg}$. At this point, the animals were slaughtered.
The experimental diet was the same for the two feeding systems, consisting of $700 \mathrm{~g} \mathrm{~kg}^{-1}$ of concentrate and $300 \mathrm{~g} \mathrm{~kg}^{-1}$ of Coast Cross hay based on the organic matter. The concentrate was consisted of corn at $490 \mathrm{~g} \mathrm{~kg}^{-1}$, soybean meal at $380 \mathrm{~g} \mathrm{~kg}^{-1}$, cottonseed meal at $100 \mathrm{~g} \mathrm{~kg}^{-1}$, limestone at $20 \mathrm{~g} \mathrm{~kg}^{-1}$, salt at $10 \mathrm{~g} \mathrm{~kg}^{-1}$, based on dry matter and formulated according to NRC (1981), for gains of $150 \mathrm{~g} \mathrm{day}^{-1}$. The composition is presented in Table 1.

Table 1. Bromatological composition of the diet, concentrate and hay based on the dry matter content.

\begin{tabular}{lccc}
\hline \multicolumn{1}{c}{ Composition } & Experimental diet & Concentrate & Hay \\
\hline MS $(\mathrm{g} / \mathrm{kg})$ & 841,1 & 832,6 & 830,7 \\
\hline PB $(\mathrm{g} / \mathrm{kg})$ & 200,1 & 285,0 & 65,7 \\
\hline $\mathrm{EE}(\mathrm{g} / \mathrm{kg})$ & 27,3 & 32,2 & 11,4 \\
\hline $\mathrm{CZ}(\mathrm{g} / \mathrm{kg})$ & 59,6 & 69,1 & 40,6 \\
\hline FB $(\mathrm{g} / \mathrm{kg})$ & 187,1 & 75,2 & 324,5 \\
\hline ENN $(\mathrm{g} / \mathrm{kg})$ & 525,9 & 538,5 & 557,8 \\
\hline $\mathrm{NDT}(\mathrm{g} / \mathrm{kg})$ & 681,3 & 785,0 & 541,1 \\
\hline FDN $(\mathrm{g} / \mathrm{kg})$ & 408,1 & 166,9 & 799,4 \\
\hline FDA $(\mathrm{g} / \mathrm{kg})$ & 203,2 & 78,6 & 410,0 \\
\hline
\end{tabular}

Each month an individual sample of milk was collected from all does to determine the milk constituents. These samples were placed in plastic tubes of $30 \mathrm{~mL}$ containing the preservative Bronopol (2-Bromo-2-Nitropropane-1,3-Diol) and sent for analysis at the Clínica do Leite of the Luiz de Quieroz College of Agriculture at the University of Sao Paulo in Piracicaba (ESALQ/USP - Piracicaba/ SP) (Table 2).

Table 2. Average composition of the goat milk $\left(\mathrm{g} \mathrm{kg}^{-1}\right)$ used for feeding the kids.

\begin{tabular}{lc}
\hline \multicolumn{1}{c}{ Components } & Composition $\left(\mathrm{g} \mathrm{kg}^{-1}\right)$ \\
\hline Total compounds & 129,40 \\
\hline Degreased dry extract & 88,00 \\
\hline Fat & 41,40 \\
\hline Protein & 35,50 \\
\hline Lactose & 44,50 \\
\hline
\end{tabular}


The average daily intake of the experimental diet/ animal was estimated by the intake in collective pens. The difference was recorded between the offered and the leftovers per pen, and the result divided by the number of animals contained in each pen.

When kids reached $30 \mathrm{~kg}$ of live weight, they were submitted to fasting of solids for 18 hours and weighed to determine the live weight at slaughter. Afterward, they were sent to slaughter in a commercial slaughterhouse, in accordance with current regulations.

At the slaughterhouse, after evisceration, the carcasses were weighed to obtain the hot carcass weight. Subsequently, the carcasses were placed in a cold room and refrigerated at $4^{\circ} \mathrm{C}$ for 24 hours. On the following day, they were reweighed to obtain the cold carcass weight.

With the aid of a $\mathrm{pH}$ meter coupled to a fine-tip penetration prob, the final $\mathrm{pHs}$ of the carcasses were recorded by introducing the electrode directly into the Longissimus lumborum muscle.

The carcass conformation and amount of fat were determined subjectively by visual assessment, considering it as a whole, taking into account the different anatomical regions, and the thicknesses of muscle and fat components relative to the skeletal size that supports it. The value 1 was attributed to very poor and 5 for excellent conformation, with 1 for excessive thin and 5 for excessive fat covering (COLOMER-ROCHER, 1988).

According to the methodology of Sañudo and Sierra (1986), the following morphometric measurements were taken: External Carcass Length: distance between the cervicothoracic junction and the first intercoccygeal joint; Internal Carcass Length: maximum distance between the front edge of the pubic bone and the front edge of the first rib at its midpoint; Leg Length: Distance between the greater trochanter and the lateral edge of the tarsometatarsal joint, all taken with tape; Rump Width: maximum width between the trochanters of the femurs; Rump Perimeter: based on the trochanters of the femurs; Thorax Depth: maximum distance between the sternum and the back of the carcass, all taken with a pair of compasses.

Carcass traits were calculated, including: carcass yield in $\mathrm{g} / \mathrm{kg}$, which is the relation between the cold carcass weight and live weight at slaughter; the carcass compactness index, a relation between the cold carcass weight and its internal length; and the leg compactness index, the relation between the rump width and leg length.

After this procedure, the carcasses were divided in half, obtaining the left half carcass, which was weighed and then sectioned into five anatomical regions according to the methods described by Yáñez (2002), resulting in the following meat cuts: neck, shoulder, rib, loin and leg.

In Longissimus lumborum muscle, in the section between the $13^{\text {th }}$ thoracic vertebra and the first lumbar vertebra, the muscle was outlined in a thin plastic sheet using a permanent marker. Subsequently, the loin eye outline of the plastic sheet was scanned and inserted into the Image Analysis Program UTHSCSA Image Tool, free software (RESENDE JÚNIOR et al., 2006) to calculate the loin eye area, in square centimeters.

The neck, shoulder, rib, loin and leg cuts were weighed to calculate their yield in relation to the carcass $\left(\mathrm{g} \mathrm{kg}^{-1}\right)$, obtaining the neck, shoulder, rib, loin and leg yields.

Considering the high correlation between the components of the carcass tissues and loin (NAUDE; HOFMEYER, 1981), the loin of the left half carcass was selected to represent the carcass. It was dissected to determine the tissue composition ( $\mathrm{g} \mathrm{kg}^{-1}$ of loin) in muscle, bone, fat and other tissue yields (connective or conjunctive tissue, arteries and veins), considering the fat subdivided in subcutaneous and intermuscular fat.

To evaluate the tenderness of the meat, the Longissimus lumborum muscles were separated and 
frozen. Thereafter, three samples were taken from each frozen muscle to form parallelepipeds with approximately $2 \times 2 \times 1.13 \mathrm{~cm}$ in accordance with the methodology of Froning et al. (1978). After this procedure, the samples were thawed in a refrigerator for a period of 24 hours at $4^{\circ} \mathrm{C}$ and then were placed in plastic bags and submitted to cooking in a water bath at $85^{\circ} \mathrm{C}$ for 20 minutes (HONIKEL, 1998), until the temperature inside of these samples reached $72^{\circ} \mathrm{C}$.

The force required to transversely cut each sample was measured using a texturometer model TA - XT PLUS (Texture Analyser) equipped with a set of Warner-Bratzler blade (LINARES et al., 2007).
The experiment was conducted in randomized block design (gender) and analyzed in a factorial arrangement using analysis of variance, with the inclusion of the covariate live weight at slaughter. The factorial consisted of five breed groups and two feeding systems. Means were compared by Tukey test $(\mathrm{P}<0.05)$. SAEG program was used for data analysis (UFV, 2000).

\section{Results and Discussion}

The intake of the animals (Table 3) was in accordance to the expected and it is similar to that proposed by the NRC (1981).

Table 3. Average daily intake of nutrients according to the feeding system.

\begin{tabular}{ccccc}
\hline \multirow{2}{*}{ Nutrient } & \multicolumn{4}{c}{ Feed System } \\
\cline { 2 - 5 } & Without milk Diet $\left(\mathrm{g} \mathrm{kg}^{-1}\right)$ & Dith milk & Milk $(1,5 \mathrm{~L})\left(\mathrm{g} \mathrm{kg}^{-1}\right)$ & Total \\
\cline { 2 - 4 } MS & 578 & 307 & 194 & 501 \\
PB & 137 & 73 & 53 & 126 \\
EE & 19 & 10 & 62 & 72 \\
CZ & 41 & 22 & - & 22 \\
FB & 128 & 68 & - & 68 \\
ENN & 361 & 192 & - & 192 \\
NDT & 468 & 249 & $-240^{*}$ & 489 \\
FDN & 280 & 149 & - & 149 \\
FDA & 139 & 74 & - & 74 \\
\hline
\end{tabular}

*Based to 700Kcal of Digestible Energy (NRC, 2007).

The live weight at slaughter for the animals in the feeding systems without milk and with milk were: 29.78 and $30.74 \mathrm{~kg}$ for Alpine; 30.10 and $30.94 \mathrm{~kg}$ for Anglo Nubian; 31.92 and $30.78 \mathrm{~kg}$ for $1 / 2$ Boer $x$ Alpine; 30.12 and $31.25 \mathrm{~kg}$ for $3 / 4$ Boer $x$ Alpine and 31.63 and $30.66 \mathrm{~kg}$ for $7 / 8$ Boer $\mathrm{x}$ Alpine, respectively.
The feeding system influenced hot carcass weight, the final $\mathrm{pH}$ and carcass yield (Table 4). Interacting with the breed group, it influenced the cold carcass weight, carcass conformation and carcass compactness index. The breed group influenced the amount of fat cover and leg compactness index (Table 5). 
Table 4. Averages for hot carcass weight, final $\mathrm{pH}$, carcass yield, amount of fat cover, leg compactness index and loin eye area of feedlot goat kids according to breed group and feeding system.

\begin{tabular}{|c|c|c|c|c|c|c|}
\hline \multicolumn{5}{|c|}{ Racial Group $^{1}$} & \multicolumn{2}{|c|}{ Feed System } \\
\hline Alpine & AN & $1 / 2 \mathrm{BA}$ & $3 / 4 \mathrm{BA}$ & $7 / 8 \mathrm{BA}$ & Without milk & With milk \\
\hline \multicolumn{7}{|c|}{ Hot carcass weight $(\mathrm{kg})$} \\
\hline 14,70 & 14,87 & 15,28 & 15,23 & 15,23 & $14,82 \mathrm{~b}$ & $15,30 \mathrm{a}$ \\
\hline \multicolumn{7}{|c|}{ pH final } \\
\hline 5,93 & 5,80 & 6,03 & 5,82 & 5,90 & $6,00 \mathrm{a}$ & $5,81 \mathrm{~b}$ \\
\hline \multicolumn{7}{|c|}{ Comercial carcass yield $\left(\mathrm{g} \mathrm{kg}^{-1}\right)$} \\
\hline 478,0 & 484,0 & 492,0 & 495,9 & 494,0 & $480,7 \mathrm{~b}$ & $496,2 \mathrm{a}$ \\
\hline \multicolumn{7}{|c|}{ Fat cover $(1-5)$} \\
\hline $2,07 \mathrm{~b}$ & $2,03 \mathrm{~b}$ & $2,12 \mathrm{ab}$ & $2,35 \mathrm{ab}$ & $2,49 \mathrm{a}$ & 2,20 & 2,22 \\
\hline \multicolumn{7}{|c|}{ Leg compactness index $(\mathrm{cm} / \mathrm{cm})$} \\
\hline $0,55 \mathrm{~b}$ & $0,60 \mathrm{~b}$ & $0,60 \mathrm{~b}$ & $0,64 \mathrm{a}$ & $0,70 \mathrm{a}$ & 0,61 & 0,61 \\
\hline \multicolumn{7}{|c|}{ Rib eye area $\left(\mathrm{cm}^{2}\right)$} \\
\hline 10,26 & 11,56 & 12,47 & 12,66 & 12,09 & 11,96 & 11,66 \\
\hline
\end{tabular}

${ }^{1}$ AN-Anglo Nubian, $1 / 2$ BA - 1/2 Boer + 1/2 Alpine, 3/4 BA - 3/4 Boer + 1/2 Alpine, 7/8 BA - 7/8 Boer + 1/2 Alpine.

*Means followed by different letters, in the same row, differ among themselves by Tuckey Test $(\mathrm{P}<0,05)$.

Table 5. Averages for cold carcass weight, carcass conformation and the carcass compactness index of feedlot goat kids according to breed group and feeding system.

\begin{tabular}{cccccc}
\hline Feed system & Rlpine & AN & $1 / 2 \mathrm{BA}$ & $3 / 4 \mathrm{BA}$ & $7 / 8 \mathrm{BA}$ \\
\hline \multicolumn{5}{c}{ Cold carcass weight $(\mathrm{kg})$} \\
\hline Without milk & $14,01 \mathrm{bB}$ & $14,53 \mathrm{bA}$ & $15,64 \mathrm{aA}$ & $14,35 \mathrm{bB}$ & $15,30 \mathrm{aA}$ \\
\hline With milk & $14,99 \mathrm{bA}$ & $14,99 \mathrm{bA}$ & $15,11 \mathrm{bA}$ & $16,06 \mathrm{aA}$ & $15,42 \mathrm{abA}$ \\
\hline \multicolumn{5}{c}{ Carcass conformation } \\
\hline Without milk & $1,90 \mathrm{~dB}$ & $2,06 \mathrm{cdA}$ & $2,50 \mathrm{abA}$ & $2,40 \mathrm{bcB}$ & $2,83 \mathrm{aA}$ \\
\hline With milk & $2,30 \mathrm{bA}$ & $1,96 \mathrm{bA}$ & $2,35 \mathrm{bA}$ & $2,93 \mathrm{aA}$ & $2,80 \mathrm{aA}$ \\
\hline \multicolumn{7}{c}{ Carcass compactiness index $(\mathrm{kg} \mathrm{cm})$} \\
\hline Without milk & $0,25 \mathrm{bB}$ & $0,29 \mathrm{aA}$ & $0,30 \mathrm{aA}$ & $0,30 \mathrm{aA}$ & $0,30 \mathrm{aA}$ \\
\hline With milk & $0,27 \mathrm{cA}$ & $0,28 \mathrm{cA}$ & $0,29 \mathrm{bcA}$ & $0,32 \mathrm{aB}$ & $0,31 \mathrm{abA}$ \\
\hline
\end{tabular}

${ }^{1}$ AN-Anglo Nubian, 1/2 BA - 1/2 Boer + 1/2 Alpine, 3/4 BA - 3/4 Boer + 1/2 Alpine, 7/8 BA - 7/8 Boer + 1/2 Alpine.

*Means followed by different letters, in the same row or column, differ among themselves by Tuckey Test $(\mathrm{P}<0,05)$.

The animals of the feeding system with milk showed greater hot carcass weight, lower final $\mathrm{pH}$ and higher carcass yield.

Regarding hot carcass weight, the results were contrary to that obtained by Manera et al. (2009), who reported that the hot carcass weight was greater the higher the intake of concentrate by kids, since animals with higher intake of feed concentrate would have higher production of rumen propionate and, therefore, more substrate to muscle growth and deposition. Nevertheless, this result indicates that the energy value of the ingested milk could produce the same effect.

The average final $\mathrm{pH}$ of the carcass, recorded 24 
$\mathrm{h}$ post-slaughter, was within the normal range for goat meat, which according Beserra et al. (2001) and Madruga et al. (2005) ranges from 5.97 to 6.32 and 5.96 to 6.03 , respectively. It indicates that the animals were correctly handled during slaughter, without exposure to stress (KADIM et al., 2006).

The lowest final $\mathrm{pH}$ observed in animals of the feeding system with milk was probably due to increased muscle glycogen concentration of kids from this feeding system, leading to a higher concentration of lactic acid. It is in agreement with Dias et al. (2008), who found an influence of the type of feeding system on the final $\mathrm{pH}$ of the meat for goat kids, and the values reported ranged from 5.57 to 5.85 .

The highest carcass yield of animals from the feeding system with milk may be related to the greater total weight of the stomach of the kids from the feeding system without milk. According to Delfa et al. (1991), the weight of non-constituent components of the carcass can affect carcass yield values.

The leg compactness index (Table 4) was higher in 3/4 and 7/8 Boer $x$ Alpine breed groups, which is in accordance with Freitas et al. (2011), who observed the influence of breed group in the leg compactness index, in which 3/4 Boer x Saanen kids showed better results than the Saanen breed group. The feeding system did not influence the leg compactness index, which is in agreement with Grande et al. (2003), who found no influence of different feeding systems in the leg compactness index in kids. The greatest leg compactness index of 3/4 and 7/8 Boer $x$ Alpine kids may have occured due to the lower leg length of these breed groups, since they are more compact.

The amount of fat cover was higher in $7 / 8$ Boer $\mathrm{x}$ Alpine breed group compared to Alpine and Anglo Nubian kid goats. Gomes et al. (2011) researching on five goat breed groups, concluded that the crossbred Boer animals showed the highest amount of fat cover. This results indicated that the greater use of the Boer contributes to increasing the fat covering in carcass.

Breeds directed for meat production have proper distribution of fat cover (STANFORD et al., 1995), though the goat has scarce fat cover. In accordance with this statement, it can be concluded that the average amount of fat cover observed in this study is considered reasonable but higher than the values reported by Menezes (2008) and Gomes et al. (2011), which may be explained by the higher slaughter weight of the kid goats in this study. The best results achieved by the crossbred kids can be explained by the increased tissue deposition per unit of carcass length in this group, which is a characteristic of great interest in obtaining higher quality carcasses.

There was no influence of the breed group and feeding system for loin eye area, agreeing with Menezes (2008), Sousa et al. (2009).

For cold carcass weight (Table 5), in the feeding system without milk, the $1 / 2$ Boer $\mathrm{x}$ Alpine and $7 / 8$ Boer $\mathrm{x}$ Alpine presented the highest values, and for the feeding system with milk, 3/4 Boer x Alpine showed greater values compared to Alpine, Anglo Nubian and 1/2 Boer x Alpine breed groups. Greater cold carcass weights was observed for Alpine and 3/4 Boer $x$ Alpine from the feeding system with milk.

The greatest cold carcass weight of animals from the feeding system with milk can be explained by the higher hot carcass weight of the kid goats of such feeding system. The results obtained in this study are consistent with the found by Mattos et al. (2006). When comparing two feeding systems, the authors found no influence of the type of feeding system on cold carcass weight of goats, and animals from the feeding system that had greater cold carcass weight had also presented greater hot carcass weight.

The feeding system with milk improved carcasses conformation of Alpine goats and 3/4 Boer x Alpine, which can be explained by the greater compactness of the animals from that breed, as they are selected 
for meat production. According to Osório (1992), the carcasses with better subjective conformation are the shorter and with higher leg compactness, which is consistent with the observed in this study.

The feeding system with milk improved carcass compactness index in Alpine and 3/4 Boer x Alpine goats, increasing the amount of tissue in the carcass possibly due to the higher energy content available for growing and gain.

The results of these carcass characteristics show that increasing Boer use improves the amount of fat covering and leg compactness index. The feeding system with milk improved carcass yield and final
$\mathrm{pH}$, highlighting the superiority of Boer breed on the characteristics: cold carcass weight, carcass conformation and carcass compactness index. This suggests that for Boer express its improver carcass capacity, it is dependent on better environmental conditions, as reported by Lôbo (2003).

For carcass morphometric measurements, the feeding system only influenced the chest depth (Table 6) and greater chest depth was observed in the feeding system with milk, agreeing with Carvalho Júnior et al. (2009). The authors, researching on kid goats, did not observe influence of feeding systems on the characteristics: external and internal carcass length, leg length and rump width.

Table 6. Averages for morphometric measurements evaluated according to breed group and feeding system.

\begin{tabular}{|c|c|c|c|c|c|c|}
\hline \multicolumn{5}{|c|}{ Racial group $^{1}$} & \multicolumn{2}{|c|}{ Feed system } \\
\hline Alpine & AN & $1 / 2 \mathrm{BA}$ & 3/4 BA & $7 / 8 \mathrm{BA}$ & Without milk & With milk \\
\hline \multicolumn{7}{|c|}{ Carcass external lenght $(\mathrm{cm})$} \\
\hline $61,60 \mathrm{a}$ & $56,60 \mathrm{bc}$ & $57,63 \mathrm{~b}$ & $54,63 \mathrm{c}$ & $55,18 \mathrm{bc}$ & 56,85 & 57,40 \\
\hline \multicolumn{7}{|c|}{ Carcass internal lenght $(\mathrm{cm})$} \\
\hline $54,45 \mathrm{a}$ & $51,14 \mathrm{bc}$ & $51,80 \mathrm{~b}$ & $48,56 \mathrm{~d}$ & $49,79 \mathrm{~cd}$ & 50,98 & 51,32 \\
\hline \multicolumn{7}{|c|}{ Leg lenght $(\mathrm{cm})$} \\
\hline $33,10 \mathrm{a}$ & $31,61 \mathrm{~b}$ & $31,16 \mathrm{~b}$ & $29,00 \mathrm{c}$ & $28,05 \mathrm{c}$ & 30,40 & 30,80 \\
\hline \multicolumn{7}{|c|}{ Rump width $(\mathrm{cm})$} \\
\hline $18,14 \mathrm{~b}$ & $18,70 \mathrm{ab}$ & $18,30 \mathrm{~b}$ & $18,73 \mathrm{ab}$ & $19,39 \mathrm{a}$ & 18,45 & 18,82 \\
\hline \multicolumn{7}{|c|}{ Rump perimeter $(\mathrm{cm})$} \\
\hline 54,44 & 54,80 & 55,55 & 55,23 & 54,90 & 54,90 & 55,08 \\
\hline \multicolumn{7}{|c|}{ Thorax depth $(\mathrm{cm})$} \\
\hline $26,71 \mathrm{a}$ & $25,81 \mathrm{a}$ & $25,60 \mathrm{ab}$ & $24,63 \mathrm{bc}$ & $24,24 \mathrm{c}$ & $25,00 \mathrm{~b}$ & $25,81 \mathrm{a}$ \\
\hline
\end{tabular}

${ }^{1}$ AN-Anglo Nubian, $1 / 2$ BA - 1/2 Boer + 1/2 Alpine, 3/4 BA - 3/4 Boer + 1/2 Alpine, 7/8 BA - 7/8 Boer + 1/2 Alpine.

*Means followed by different letters, in the same row, differ among themselves by Tuckey Test $(\mathrm{P}<0,05)$.

The breed group influenced all characteristics except rump perimeter. Considering the lengths of carcasses and leg, and chest depth measurements, Alpine kids showed greater measurements, followed by Anglo Nubian. The crossbred goats had lower measurements the higher the use of Boer breed. These results are consistent with Menezes (2008) and Gomes et al. (2011), who verified influence of breed group on internal and external carcass length and leg length, and Alpine showed longer carcasses than crossbred Boer goats. According to Dhanda et al. (1999), Alpine goats have a taller and longilineal body structure, possibly because they are dairy animals. Among other features, dairy goats have wide, long, deep and voluminous body (MEDEIROS, 2009). 
For rump width, the greatest use of the Boer breed helped to raise this characteristic, which means the use of Boer leads to a carcass compaction, as already determined for the carcass and leg compactness indexes. This result contrasts the found by Menezes (2008), who verified no influence of the breed group in the rump width, when comparing several breed groups of dairy and crossbread meat goats.
Relative to meat cuts yields, interaction between the feeding system and breed group for some cuts was observed (Table 7). The prime cuts (leg and loin) represented a yield of $460.3 \mathrm{~g} \mathrm{~kg}^{-1}$, while the choice meat (shoulder) presented a yield of 217.3 $\mathrm{g} \mathrm{kg}^{-1}$ and the select meat (neck and rib) of $322.2 \mathrm{~g}$ $\mathrm{kg}^{-1}$. Despite considered a choice meat, the shoulder has great commercial value.

Table 7. Average yields of the rib, loin and leg of feedlot goat kids according to breed group and feeding system.

\begin{tabular}{|c|c|c|c|c|c|c|}
\hline \multicolumn{5}{|c|}{ Racial group $^{1}$} & \multicolumn{2}{|c|}{ Feed system } \\
\hline Alpine & AN & $1 / 2 \mathrm{BA}$ & $3 / 4 \mathrm{BA}$ & 7/8 BA & Witkout milk & With milk \\
\hline \multicolumn{7}{|c|}{ Rib yield $\left(\mathrm{g} \mathrm{kg}^{-1}\right)$} \\
\hline 245,5 & 238,7 & 245,8 & 242,4 & 240,7 & $236,0 \mathrm{~b}$ & $249,3 \mathrm{a}$ \\
\hline \multicolumn{7}{|c|}{ Loin yield $\left(\mathrm{g} \mathrm{kg}^{-1}\right)$} \\
\hline 157,3 & 163,3 & 160,5 & 161,2 & 163,0 & 160,4 & 161,6 \\
\hline \multicolumn{7}{|c|}{ Leg yield $\left(\mathrm{g} \mathrm{kg}^{-1}\right)$} \\
\hline $303,5 \mathrm{ab}$ & $305,5 \mathrm{a}$ & $302,1 \mathrm{ab}$ & $295,4 \mathrm{ab}$ & $290,4 \mathrm{~b}$ & 301,8 & 296,9 \\
\hline
\end{tabular}

${ }^{1}$ AN-Anglo Nubian, $1 / 2$ BA - 1/2 Boer + 1/2 Alpine, 3/4 BA - 3/4 Boer + 1/2 Alpine, 7/8 BA - 7/8 Boer + 1/2 Alpine.

* Means followed by different letters, in the same row, differ among themselves by Tuckey Test $(\mathrm{P}<0,05)$.

The sum of the yields of meat cuts considered prime and choice grades was equivalent to almost $700.0 \mathrm{~g} \mathrm{~kg}^{-1}$, which is considered good and it is related to the greater amount of muscle tissue of these cuts. These yields were higher than the found by Menezes (2008), taking into account greatest yields of prime cuts and lower yields from select cuts, which is desirable.
The feeding system with milk increased rib yield and reduced shoulder yield in Alpine and 3/4 Boer $\mathrm{x}$ Alpine goats (Table 8).

The highest rib yield (Table 7) of animals from the feeding system with milk may have occurred because in this region the fat accumulates in greater speed (MATTOS et al., 2006).

Table 8. Average yields of neck and shoulder of feedlot goat kids according to breed group and feeding system.

\begin{tabular}{|c|c|c|c|c|c|}
\hline \multirow[t]{2}{*}{ Feed system } & \multicolumn{5}{|c|}{ Racial group $^{1}$} \\
\hline & Alpine & AN & $1 / 2 \mathrm{BA}$ & $3 / 4 \mathrm{BA}$ & 7/8 BA \\
\hline \multicolumn{6}{|c|}{ Neck yield $\left(\mathrm{g} \mathrm{kg}^{-1}\right)$} \\
\hline Sem leite & $76,4 \mathrm{aA}$ & $80,1 \mathrm{aA}$ & $77,8 \mathrm{aA}$ & $86,7 \mathrm{aA}$ & $80,6 \mathrm{aA}$ \\
\hline Com leite & $85,6 \mathrm{aA}$ & $86,1 \mathrm{aA}$ & $68,0 \mathrm{bA}$ & $76,8 \mathrm{abA}$ & $74,3 \mathrm{abA}$ \\
\hline \multicolumn{6}{|c|}{ Shoulder yield $\left(\mathrm{g} \mathrm{kg}^{-1}\right)$} \\
\hline Sem leite & $220,5 \mathrm{abA}$ & $210,6 \mathrm{bA}$ & $218,3 \mathrm{abA}$ & $230,0 \mathrm{aA}$ & $226,7 \mathrm{aA}$ \\
\hline Com leite & $206,1 \mathrm{bB}$ & $208,6 \mathrm{bA}$ & $215,7 \mathrm{abA}$ & $207,7 \mathrm{bB}$ & $228,5 \mathrm{aA}$ \\
\hline
\end{tabular}

${ }^{1}$ AN-Anglo Nubian, $1 / 2$ BA - 1/2 Boer + 1/2 Alpine, 3/4 BA - 3/4 Boer + 1/2 Alpine, 7/8 BA - 7/8 Boer + 1/2 Alpine.

* Means followed by different letters, in the same row or column, differ among themselves by Tuckey Test $(\mathrm{P}<0,05)$. 
Relative to rib yield, the result of this study is in agreement with the findings of Rodrigues (2009), who reported values of 257.6 and $267.0 \mathrm{~g} \mathrm{~kg}^{-1}$ for the respective feeding systems. The average rib yield in this study was higher than the observed by Freitas et al. (2011), which found values between 160.2 and $190.7 \mathrm{~g} \mathrm{~kg}^{-1}$.

There was no influence of feeding system and breed group on loin yield, agreeing with Ferreira (2010), which also found no influence of different breed groups of goats (Anglo Nubian, 1/2 Anglo Nubian x Boer, Alpine and crossbred Alpine x meat goat) on this characteristic. The result for loin yield may be explained by the law of anatomical harmony enunciated by Boccard and Dumont (1960), according to which, in carcasses of similar weights, almost all body regions are in similar proportions, regardless the conformation of the considered genotypes.

The 7/8 Boer x Alpine kid goats had lower leg yield than Anglo Nubians, and these do not differ from the others. The neck yield of kids from the feeding system with milk was higher in Alpine and Anglo Nubian goats than in 1/2 Boer x Alpine, and these did not differ from the other groups. The shoulder yield in animals from the feeding system without milk was higher in $3 / 4$ and $7 / 8$ Boer $x$ Alpine goats in relation to Anglo Nubians, and in the feeding system with milk the $7 / 8$ breed group was superior than the Alpine, Anglo Nubians and $3 / 4$ Boer x Alpine.

These results indicate that the increased use of Boer leads to a decrease in leg yield by reducing its length, and its greater compactness is not enough to reverse this trend in this estimated weight. The same can be said about the neck yield. For shoulder yield, the results suggest that the use of Boer contributes to its increase. The results of this study regarding shoulder yield are similar to those obtained by Rodrigues (2009), which found an influence of two feeding systems and five different breed groups on shoulder yield of different goat breed groups (dairy and crossbred milk + meat goats).

Leg yield in this study was similar to the found by Menezes (2008). However, differs from the results of Lisboa et al. (2010), Ferreira (2010) and Freitas et al. (2011), which found no influence of different breed groups on leg yield in goats. This characteristic is economically important since it has high commercial value, considering it is a prime cut.

The average shoulder yield found in this study was higher than that observed by Lisboa et al. (2010), who reported 213.2. Nevertheless, it was lower than the values recorded by Carvalho Júnior et al. (2009), who found $217.9 \mathrm{~g} \mathrm{~kg}^{-1}$.

The average yield for neck found in this study was higher than verified by Freitas et al. (2011), who observed $64.6 \mathrm{~g} \mathrm{~kg}^{-1}$, although lower than the found by Carvalho Júnior et al. (2009) and Ferreira (2010), who reported 105.1 and $90.3 \mathrm{~g} \mathrm{~kg}^{-1}$, respectively.

Muscular tissue showed the higher proportion, with an average participation of $631.10 \mathrm{~g} / \mathrm{kg}$ relative to the total of the loin cut, followed by total fat with an average of $180.00 \mathrm{~g} \mathrm{~kg}^{-1}$, and bone, averaging $141.80 \mathrm{~g} \mathrm{~kg}^{-1}$ (Table 9). Although Silva (2005) found better values than the obtained in this study (715.50, 162.00 and $122.60 \mathrm{~g} \mathrm{~kg}^{-1}$ for muscle, fat and bone, respectively), the result of this study is considered very satisfactory and beyond the recorded by Oman et al. (1999), Menezes (2008) and Ferreira (2010).

The feeding system influenced total loin weight, muscle yield and intermuscular fat. Interacting with the breed group, it influenced the yield of subcutaneous fat and total fat, and the breed group influenced muscle and intermuscular fat yields. 
Table 9. Averages for total loin weight, muscle, bone, other tissues and intermuscular loin fat yields of feedlot goat kids according to breed group and feeding system.

\begin{tabular}{|c|c|c|c|c|c|c|}
\hline \multicolumn{5}{|c|}{ Racial Group $^{1}$} & \multicolumn{2}{|c|}{ Feed system } \\
\hline Alpine & AN & $1 / 2 \mathrm{BA}$ & $3 / 4 \mathrm{BA}$ & 7/8 BA & Without milk & With milk \\
\hline \multicolumn{7}{|c|}{ Loin weight $(\mathrm{g})$} \\
\hline 1106,70 & 1173,60 & 1187,30 & 1166,08 & 1186,06 & $1141,13 \mathrm{~b}$ & $1186,81 \mathrm{a}$ \\
\hline \multicolumn{7}{|c|}{ Muscle yield $\left(\mathrm{g} \mathrm{kg}^{-1}\right)$} \\
\hline $601,80 \mathrm{~b}$ & $638,50 \mathrm{a}$ & $641,80 \mathrm{a}$ & $627,10 \mathrm{ab}$ & $646,40 \mathrm{a}$ & $639,40 \mathrm{a}$ & $622,90 \mathrm{~b}$ \\
\hline \multicolumn{7}{|c|}{ Bone yield $\left(\mathrm{g} \mathrm{kg}^{-1}\right)$} \\
\hline 160,60 & 141,80 & 137,10 & 132,50 & 137,10 & 147,40 & 136,20 \\
\hline \multicolumn{7}{|c|}{ Other tissues yield $\left(\mathrm{g} \mathrm{kg}^{-1}\right)$} \\
\hline 46,50 & 48,00 & 46,00 & 47,30 & 48,00 & 48,40 & 45,90 \\
\hline \multicolumn{7}{|c|}{ Intermuscular fat yield $\left(\mathrm{g} \mathrm{kg}^{-1}\right)$} \\
\hline $109,30 \mathrm{a}$ & $95,70 \mathrm{ab}$ & $93,90 \mathrm{ab}$ & $106,00 \mathrm{a}$ & $79,60 \mathrm{~b}$ & $91,10 \mathrm{~b}$ & $102,60 \mathrm{a}$ \\
\hline
\end{tabular}

${ }^{1}$ AN-Anglo Nubian, $1 / 2$ BA - 1/2 Boer + 1/2 Alpine, 3/4 BA - 3/4 Boer + 1/2 Alpine, 7/8 BA - 7/8 Boer + 1/2 Alpine.

* Means followed by different letters, in the same row, differ among themselves by Tuckey Test $(\mathrm{P}<0,05)$.

The feeding system with milk increased the overall loin weight and the yield of intermuscular fat, but decreased muscle yield, besides increased yields of subcutaneous fat and total fat in Alpine, 3/4 and 7/8 Boer x Alpine breed groups.

Since the adipose tissue is considered a delayed deposition tissue (OWENS et al., 1993), the feeding system with milk anticipated this tissue deposition in the carcass probably due to the higher energy and fat content of such feeding system, which can be considered beneficial for improving goat carcasses.

The muscle yield was lower in animals of the Alpine breed compared to Anglo Nubians, 1/2 and 7/8 Boer x Alpine. On the other hand, Alpine and 3/4 Boer x Alpine breed groups presented higher intermuscular fat yield in relation to $7 / 8$ Boer $\mathrm{x}$
Alpine. The better results shown by Anglo Nubians and crossbred Boer goats for muscle yield are in accordance with Stanford et al. (1995), which stated that breeds selected for meat production have better carcass conformation due to the development of muscle mass. Anglo Nubians kids of the feeding system with milk had lower subcutaneous fat yield compared to 7/8 Boer x Alpine; and Anglo Nubians and $1 / 2$ Boer $\mathrm{x}$ Alpine from the feeding system with milk had lower total fat yields relative to $3 / 4$ Boer $\mathrm{x}$ Alpine of that same feeding system.

The highest values observed for the yields of intermuscular fat, subcutaneous fat and total fat in kid goats of the feeding system with milk (Table 10) are explained by the higher deposition capacity of fat that this feeding system provided, in terms of its higher energy and fat content. 
Table 10. Average yields of subcutaneous fat and total loin of feedlot goat kids according to breed group and feeding system.

\begin{tabular}{cccccc}
\hline Feed System & Rlpine & AN & $1 / 2 \mathrm{BA}$ & $3 / 4 \mathrm{BA}$ & $7 / 8 \mathrm{BA}$ \\
\hline \multicolumn{5}{c}{ Subcutaneous fat yield $\left(\mathrm{g} \mathrm{kg}^{-1}\right)$} \\
\hline Without milk & $67,5 \mathrm{aB}$ & $75,8 \mathrm{aA}$ & $80,9 \mathrm{aA}$ & $73,9 \mathrm{aB}$ & $70,7 \mathrm{aB}$ \\
\hline With milk & $94,3 \mathrm{abA}$ & $76,2 \mathrm{bA}$ & $83,0 \mathrm{abA}$ & $100,9 \mathrm{abA}$ & $107,6 \mathrm{aA}$ \\
\hline \multicolumn{5}{c}{ Total fat yield $\left(\mathrm{g} \mathrm{kg}^{-1}\right)$} \\
\hline Without milk & $165,5 \mathrm{aB}$ & $162,0 \mathrm{aA}$ & $182,2 \mathrm{aA}$ & $162,8 \mathrm{aB}$ & $152,1 \mathrm{aB}$ \\
\hline With milk & $208,5 \mathrm{abA}$ & $179,4 \mathrm{bA}$ & $176,4 \mathrm{bA}$ & $224,6 \mathrm{aA}$ & $189,6 \mathrm{abA}$ \\
\hline
\end{tabular}

${ }^{1}$ AN-Anglo Nubian, $1 / 2$ BA - 1/2 Boer + 1/2 Alpine, 3/4 BA - 3/4 Boer + 1/2 Alpine, 7/8 BA - 7/8 Boer + 1/2 Alpine.

*Means followed by different letters, in the same row or column, differ among themselves by Tuckey Test $(\mathrm{P}<0,05)$.

The average values of intermuscular fat, subcutaneous fat and total fat yields observed in this study were lower than the obtained by Peña et al. (2007); Menezes (2008) and Grande et al. (2003), who found 106.1; 105.8 and $210.4 \mathrm{~g} \mathrm{~kg}^{-1}$, respectively.

The result for total loin weight observed in this study was similar to the verified by Dias et al. (2008), who reported the influence of feeding systems on this characteristic. The carcass composition, considering animals of similar weights and ages, can be affected by the feeding system, once the nutrient levels produces variations on animal ponderal growth and, therefore, in the ratio and growth of the cuts (EMERSON, 2012).

The greatest muscle yields of animals on the feeding system without milk can be explained by the lower fat content of these kid goats. It is in agreement with Freitas et al. (2011), who found influence of feeding systems on the muscle yield of $3 / 4$ Boer x Saanen and Saanen goats, slaughtered with an average weight of $30 \mathrm{~kg}$, obtaining values of 708.9; 735.8 and $695.2 \mathrm{~g} \mathrm{~kg}^{-1}$ for the three feeding systems used.

The results presented in this study for muscle yield according to the breed group were similar to those verified by Santos et al. (2007) and Ferreira (2010) researching on Serrana, Bravia and Serrana x Bravia and Anglo-Nubian, Boer x Anglo-Nubian and $3 / 4$ Boer $\mathrm{x}$ mixed breed goats, slaughtered between 8 and $11 \mathrm{~kg}$ and 20 and $25 \mathrm{~kg}$ of body weight, respectively.

The lowest muscle yield of Alpine observed in this study was explained by this breed is specialized for milk production, and therefore they have more longilineal body (MEDEIROS, 2009).

Bone and other tissues yields were not affected by the feeding system, breed group and by the interaction of these two sources of variation, agreeing with Grande et al. (2003), Santos et al. (2007) and Menezes (2008), respectively. On the other hand, differ from the results obtained by Emerson (2012), which found an influence of breed group and feeding system on bone yield for goats. In that study, Alpine breed group showed higher bone yield than 1/2 Boer x Alpine, and animals from grazing feeding system had lower bone yields than the feedlot animals. One possible explanation is that Alpine breed goats are dairy animals and consequently present inferior carcass characteristics to those specialized breeds for meat production (RODRIGUES, 2009), and regarding animals finished on pasture, they exhibited lower body development (EMERSON, 2012).

The average yields of bone and other tissues found in this study were lower than the reported by 
Grande et al. (2003), Santos et al. (2007), Menezes (2008) and Ferreira (2010), who observed 161.1; $170.0 ; 209.5 ; 151.7$ and $227.4 \mathrm{~g} \mathrm{~kg}^{-1}$. In addition, Rodrigues (2009) observed $88.0 \mathrm{~g} \mathrm{~kg}^{-1}$, this data, allow to conclude that the observed in this study is in agreement with the standards found for animals of this age. And, this result is desirable since the smaller the value of these characteristics the greater the yield of primal tissues.
Regarding the tenderness of the meat, there were no influences of the breed group and feeding system (Table 11), as well as interaction between breed group and feeding system. These results agree with Menezes (2008) and Rodrigues (2009), researching on goats of different breed groups (dairy and meat crossbred goats) and Johnson et al. (2010) with crossbred Boer goats fed two diets, with forage and forage with grains, and slaughtered with an average live weight of $36.4 \mathrm{~kg}$.

Table 11. Averages of the tenderness of the meat of feedlot goat kids according to breed group and feeding system.

\begin{tabular}{ccccccc}
\hline & \multicolumn{3}{c}{ Racial group $^{1}$} & \multicolumn{2}{c}{ Feed system } \\
\hline Alpine & AN & $1 / 2 \mathrm{BA}$ & $3 / 4 \mathrm{BA}$ & $7 / 8 \mathrm{BA}$ & Without milk & With milk \\
\hline \multicolumn{3}{c}{} & & Tenderness $(\mathrm{kg})$ & & \\
\hline 7,98 & 9,07 & 7.62 & 7,80 & 7,73 & 7,70 & 8,37 \\
\hline
\end{tabular}

${ }^{1}$ AN-Anglo Nubian, $1 / 2$ BA - 1/2 Boer + 1/2 Alpine, 3/4 BA - 3/4 Boer + 1/2 Alpine, $7 / 8$ BA - 7/8 Boer + 1/2 Alpine.

On the other hand, Dhanda et al. (2003) and Peña et al. (2007) found influence of breed group on tenderness of the loin meat in Feral, Boer x Angora, Boer x Feral, Boer x Saanen, Saanen x Angora, Saanen x Feral, Criollo Cordobes and Anglo Nubian goats, slaughtered with average live weight of 25 to $27 \mathrm{~kg}$ and 10 to $12 \mathrm{~kg}$, respectively. Bañón et al. (2006) and Lisboa (2008) found influence of the feeding system in the tenderness of the loin meat in goats slaughtered with an average weight of $7.6 \mathrm{~kg}$ and 18.81 to $20.49 \mathrm{~kg}$, and the feeding system using a substitute for goat's milk showed a more tender meat than those that used only goat's milk, and the feeding system that contained higher energy level presented more tender meat, respectively.

The averages for tenderness ranged from 7.62 to $9.07 \mathrm{~kg}$, which are classified as acceptable (SOUZA et al., 2004; MADRUGA, 2004). In the literature a variety of results can be found and it is assigned, for example, to differences in nutrition, age, time and cooking temperature (RODRIGUES, 2009).

In this study, the tenderness of the meat was not influenced by any of the variables, since all animals have been slaughtered at an early age and also because it is directly related to other factors such as $\mathrm{pH}$, fat content in the carcass (KOOHMARAIE et al., 1990), temperature control in the first 24 hours post-slaughter and management practices used before slaughter (BRESSAN et al., 2001), which were the same for all.

\section{Conclusions}

The feeding system changes goat carcass characteristics, and the kid goats fed milk until slaughter have better carcass yield and meat quality, as it anticipates the deposition of total fat, which can benefit the carcass quality, given the scarcity of fat in the carcass of goats.

The breed group also influences carcass characteristics. It is recommended the use of the Boer breed up to 3/4, since more than that it reduces leg yield and does not improve the compactness index and carcass conformation. 


\section{References}

BAÑÓN, S.; VILA, R.; PRICE, A.; FERRANDINI, E.; GARRIDO, M. D. Effects of goat milk or milk replacer diet on meat quality and fat composition of suckling goat kids. Meat Science, Savoy, v. 72, n. 2, p. 216-221, 2006.

BESERRA, F. J.; MOURA, R. P.; SILVA, E. M. C.; MADRUGA, M. S. Características químicas e físicoquímicas da carne de caprinos SRD com diferentes pesos de abate. Revista Tecnologia de Carnes, Campinas, v. 3, n. 2, p. 1-6, 2001.

BOCCARD, R.; DUMONT, B. L. Étude de la production de la viande chez les ovins. II. Variation de l'importance relative des différents régions corporelles de l'agneau de boucherie. Annales de Zootechnie, v. 9, n. 4, p. 355-365, 1960.

BRESSAN, M. C.; PRADO, O. V.; PÉREZ, J. R. O.; LEMOS, A. L. S. C.; BONAGURIO, S. Efeito do peso ao abate de cordeiros Santa Inês e Bergamácia sobre as características físico-químicas da carne. Ciência e Tecnologia de Alimentos, Campinas, v. 21, n. 3, p. 293303, 2001.

CARVALHO JÚNIOR, A. M. de; PEREIRA FILHO, J. M.; SILVA, R. M.; CESAR, M. F.; SILVA, A. M. A.; SILVA, A. L. N. Efeito da suplementação nas características de carcaça e dos componentes não-carcaça de caprinos $\mathrm{F}_{1}$ Boer $\mathrm{x}$ SRD terminados em pastagem nativa. Revista Brasileira de Zootecnia, Viçosa, MG, v. 38, n. 7, p. 1301-1308, 2009.

COLOMER-ROCHER, F. Estudio de los parametros que definem los caracteres cuantitativos y cualitativos de las canales. In: CURSO INTERNACIONAL SOBRE PRODUCCIÓN DE CARNE Y LECHE CON BASES EN PASTOS Y FORRAGES, 1988, La Coruña. Anales... La Coruña: Espanha, 1988. 108 p.

DELFA, R.; GONZALEZ, C.; TEIXEIRA, A. El quinto cuarto. Revista Ovis, Zaragoza, v. 17, p. 48-68, 1991.

DELFA, R.; TEIXEIRA, A.; GONZALEZ, Y. C. Composición de la canal: medida de la composición. Revista Ovis, Zaragoza, v. 2, n. 23, p. 9-22, 1992.

DHANDA, J. S.; TAYLOR, D. G.; MCCOSKER, J. E.; MURRAY, P. J. The influence of goat genotype on the production of Capreto and Chevon carcasses. 1. Growth and carcass characteristics. Meat Science, Savoy, v. 52, n. 1-2, p. 355-361, 1999.

DHANDA, J. S.; TAYLOR, D. G.; MURRAY, P. J. Growth, carcass and meat quality parameters of male goats: effects of genotype and liveweight at slaughter. Part 1. Small Ruminant Research, Amsterdam, v. 50, n. 1-2, p. 57-66, 2003.
DIAS, A. M. A.; MACIEL, M. I. S.; BATISTA, A. M. V.; CARVALHO, F. F. R.; GUIM, A.; SILVA, G. Inclusão do farelo grosso de trigo na dieta e seu efeito sobre as propriedades físicas e sensoriais da carne caprina. Ciência e Tecnologia de Alimentos, Campinas, v. 28, n. 3, p. 527-533, 2008.

EMERSON, M. S. Predição da composição tecidual da carcaça de cabritos de diferentes grupos raciais a partir de cortes cárneos. 2012. Dissertação (Mestrado em Zootecnia) - Faculdade de Medicina Veterinária e Zootecnia. Universidade Estadual Paulista, Botucatu.

FERREIRA, L. Desempenho produtivo e características de carcaça de caprinos com diferentes composições raciais. 2010. Dissertação (Mestrado em Ciências) - Universidade Federal Rural do Rio de Janeiro, Seropédica.

FREITAS, H. S.; ALCADE, C. R.; LIMA, L. S. de.; MACEDO, F. A. F.; MACEDO, V. P.; MOLINA, B. S. L. Quantitative characteristics of carcass and meat quality of 3/4 Boer + 1/4 Saanen and Saanen goat kids fed diets with dry yeast. Revista Brasileira de Zootecnia, Viçosa, MG, v. 40, n. 3, p. 630-638, 2011.

FRONING, G. W.; BABJI, A. S.; MATHER, F. B. The effect of preslaughter temperatures, stress, struggle and anesthetiztion on color and textural characteristics of turkey muscle. Poultry Science, Savoy, v. 57, n. 3, p. 630633, 1978.

GOMES, H. F. B.; MENEZES, J. J. L. de; GONÇALVES, H. C.; CANIZARES, G. I. L.; MEDEIROS, B. B. L.; POLIZEL NETO, A.; LOURENÇON, R. V.; CHAVARI, A. C. T. Características de carcaça de caprinos de cinco grupos raciais criados em confinamento. Revista Brasileira de Zootecnia, Viçosa, MG, v. 40, n. 2, p. 411417, 2011.

GRANDE, P. A.; ALCADE, C. R.; MACEDO, F. A. F. de.; YAMAMOTO, S. M.; MARTINS L. N. Desempenho e características de carcaça de cabritos da raça Saanen recebendo rações com farelo de glúten do milho e/ ou farelo de soja. Acta Scientiarum. Animal Science, Maringá, v. 25, n. 2, p. 315-321, 2003.

HONIKEL, K. O. Reference methods for the assessment of physical characteristics of meat. Meat Science, Savoy, v. 49, n. 4, p. 447-457, 1998.

JOHNSON, C. R.; DOYLE, S. P.; LONG, R. S. Effect of feeding system on meat goat growth performance and carcass traits. Sheep \& Goat Research Journal, Lincoln, v. 25, n. 4 , p. $78-82,2010$.

KADIM, I. T.; MAHGOUB, O.; AL-KINDI, A.; AL-MARZOOGI, W.; AL-SAQRI, N. M. Effects of transportation at high ambient temperatures on 
physiological responses, carcass and meat quality characteristics of three breeds of Omani goats. Meat Science, Savoy, v. 73, n. 4, p. 626-634, 2006.

KOOHMARAIE, M.; WHIPPLE, G.; CROUSE, J. D. Acceleration of postmortem tenderization in lambs and Brahman-cross beef carcasses through infusion of calcium chloride. Journal of Animal Science, Champaign, v. 68 , n. 5 , p. $1278-1283,1990$.

LINARES, M. B.; BÓRNEZ, R.; VERGARA, H. Effect of different stunning systems on meat quality of light lamb. Meat Science, Savoy, v. 76, n. 4, p. 675-681, 2007.

LISBOA, A. C. C. Características da carcaça de caprinos das raças Canindé e Moxotó criados em confinamento $e$ alimentados com dietas contendo dois níveis de energia. 2008. Dissertação (Mestrado em Zootecnia) Universidade Federal da Paraíba, Areia.

LISBOA, A. C. C.; FURTADO, D. A.; MEDEIROS, A. N. de.; COSTA, R. G.; QUEIROGA, R. C. E.; BARRETO, L. M. G. Quantitative characteristics of the carcasses of Moxotó and Canindé goats fed diets with two different energy levels. Revista Brasileira de Zootecnia, Viçosa, MG, v. 39, n. 7, p. 1565-1570, 2010.

LÔBO, R. N. B. Cruzamento industrial: quando e como fazer? In: SEMINÁRIO NORDESTINO DE PECUÁRIA, PECNORDESTE, CAPRINO-OVINOCULTURA, 7., 2003, Fortaleza. Anais... Fortaleza: FAEC, 2003, p. 8195.

MADRUGA, M. S. Processamento e características físicas e organolépticas das carnes caprina e ovina. In: SEMANA DE CAPRINOCULTURA E OVINOCULTURA BRASILEIRA, 2004, João Pessoa. Anais... João Pessoa: UFPB, 2004. CD-ROM.

MADRUGA, M. S.; NARAIN, N.; DUARTE, T. F.; SOUZA, W. H.; GALVÃO, M. S.; CUNHA, M. G. G.; RAMOS, J. L. Características químicas e sensoriais de cortes comerciais de caprinos SRD e mestiços Boer. Ciência e Tecnologia Alimentos, Campinas, v. 25, n. 4, p. 713-719, 2005.

MANERA, D. B.; VOLTOLINI, T. V.; MASCIOLI, A. S.; BARBOSA, L. D.; SOUZA, R. A. Desempenho produtivo e características de carcaça de cabritos alimentados com diferentes proporções de concentrado. Revista Caatinga, Mossoró, v. 22, n. 4, p. 240-245, 2009.

MANFREDINI, M.; MASSARI, M.; CAVANI, C.; FALASCHINI, A. F. Carcass characteristics of male Alpine kids slaughtered at different weights. Small Ruminant Research, Amsterdam, v. 1, n. 1, p. 49-58, 1988.

MATTOS, C. W.; CARVALHO, F. F. R. de; DUTRA JÚNIOR, W. M.; VERAS, A. S. C.; BATISTA, A. M.
V.; ALVES, K. S.; RIBEIRO, V. R.; SILVA, M. J. M. S.; MEDEIROS, G. R.; VASCONCELOS, M. R. J.; ARAUJO, A. O.; MIRANDA, S. B. Características de carcaça e dos componentes não-carcaça de cabritos Moxotó e Canindé submetidos a dois níveis de alimentação. Revista Brasileira de Zootecnia, Viçosa, MG, v. 35, n. 5, p. 2125-2134, 2006.

MEDEIROS, L. F. D. Julgamento de caprinos e ovinos - julgamento animal. Seropédica: Universidade Federal Rural do Rio de Janeiro - Instituto de Zootecnia Departamento de Reprodução e Avaliação Animal, 2009. 31 p. Apostila.

MENEZES, J. J. L. de. Desempenho e características de carcaça de cabritos de diferentes grupos raciais e pesos de abate. 2008. Tese (Doutorado em Zootecnia) - Faculdade de Medicina Veterinária e Zootecnia. Universidade Estadual Paulista, Botucatu.

NATIONAL RESEARCH COUNCIL - NRC. Nutrient requirements of goats. Washington: National Academies Press, $1981.91 \mathrm{p}$.

. Nutrient requirements of small ruminants. Sheep, goat, cervids and new world camelids. Washington: National Academies Press, 2007. 362 p.

NAUDE, R. T.; HOFMEYR, H. S. Meat production. In: _. Goat production. London: Academic Press, 1981.p. 285-307.

OMAN, J. S.; WALDRON, D. F.; GRIFFIN, D. B.; SAVELL, J. W. Effect of breed-type and feeding regimen on goat carcass traits. Journal of Animal Science, Champaign, v. 77, n. 12, p. 3215-3218, 1999.

OSÓRIO, J. C. S. Estudio de la calidad de canales comercializadas en el tipo ternasco segun la procedencia: Bases para la mejora de dicha calidad en Brasil. 1992. Tesis (Doctoral) - Facultad de Veterinária. Universidad de Zaragoza, Zaragoza.

OWENS, F. N.; DUBESKI, P.; HANSON, C. F. Factors that alter the growth and development of ruminants. Journal of Animal Science, Champaign, v. 71, n.11, p. 3138-3150, 1993.

PEÑA, F.; PEREA, J.; GARCÍA, A.; ACERO, R. Effects of weight at slaughter and sex on the carcass characteristics of Florida suckling kids. Meat Science, Savoy, 75, n. 3, p. 543-550, 2007.

RESENDE JÚNIOR, J. C.; ALONSO, L. S.; PEREIRA, M. N.; MAGALHÃES, M. G. R.; DUBOC, M. V.; OLIVEIRA, E. C.; MELO, L. Q. Effect of the feeding pattern on rumen wall morphology of cows and sheep. Brazilian Journal of Veterinary Research and Animal Science, São Paulo, v. 43, n. 4, p. 526-536, 2006. 
RODRIGUES, L. Sistemas de produção de caprinos de leite e carne em pasto ou confinamento. 2009. Tese (Doutorado em Zootecnia) - Faculdade de Medicina Veterinária e Zootecnia. Universidade Estadual Paulista, Botucatu.

SANTOS, V. A. C.; SILVA, A. O.; CARDOSO, J. V. F.; SILVESTRE, A. J. D.; SILVA, S. R.; MARTINS, C.; AZEVEDO, J. M. T. Genotype and sex effects on carcass and meat quality of suckling kids protected by the PGI Cabrito de Barroso. Meat Science, Savoy, v. 75, n. 4, p. 725-736, 2007.

SAÑUDO, C.; SIERRA, I. Calidad de la canal en la especie ovina. Ovino, Zaragoza, v. 1, p. 127-153, 1986.

SILVA, K. T. Desempenho, digestibilidade $e$ características de carcaças de cabritos mestiços Boer $x$ Saanen confinados, recebendo rações com diferentes níveis energéticos. 2005. Dissertação (Mestrado em Zootecnia) - Universidade Estadual de Maringá, Maringá.

SOUSA, W. H. de; BRITO, E. A.; MEDEIROS, A. N. de.; CARTAXO, F. Q.; CESAR, M. F.; CUNHA, M. G. G. Características morfométricas e da carcaça de cabritos e cordeiros terminados em confinamento. Revista
Brasileira de Zootecnia, Viçosa, MG, v. 38, n. 7, p. 13401346, 2009.

SOUZA, X. R.; BRESSAN, M. C.; PÉREZ, J. R. O.; FARIA, P. B.; VIEIRA, J. O.; KABEYA, D. M. Efeitos do grupo genético, sexo e peso ao abate sobre as propriedades físico-químicas da carne de cordeiros em crescimento. Ciência e Tecnologia de Alimentos, Campinas, v. 24, n. 4, p. 543-549, 2004.

STANFORD, K.; MCALLISTER, T. A.; MACDOUGALL, M.; BAILEY, D. R. C. Use of ultrasound for the prediction of carcass characteristics in Alpine goats. Small Ruminant Research, Amsterdam, v. 15, n. 2, p. 195-201, 1995.

UNIVERSIDADE FEDERAL DE VIÇOSA - UFV. Sistema de análises estatísticas e genéticas - SAEG. Versão 8.0. Viçosa, MG: Editora UFV, 2000. 142 p.

YÁÑEZ, E. A. Desenvolvimento relativo dos tecidos e características de carcaça de cabritos Saanen, com diferentes pesos e niveis nutricionais. 2002. Tese (Doutorado em Zootecnia) - Faculdade de Ciências Agrárias e Veterinárias. Universidade Estadual Paulista, Jaboticabal. 